\title{
Etosom sebagai Penghantar Obat Herbal Hidrofilik
}

\author{
Luthfia Azzahra*, Ida Musfiroh \\ Program Studi Profesi Apoteker, Fakultas Farmasi, Universitas Padjadjaran, Sumedang 45363 \\ *email: lilycyntia123@gmail.com
}

\section{Abstrak :}

Sediaan herbal banyak mengandung zat aktif yang bersifat hidrofilik, sehingga terdapat masalah utama jika dibuat dalam bentuk sediaan topikal, yaitu saat proses penghantaran dan penetrasi obat menembus kulit. Oleh karena itu sebagai upaya untuk mengatasi masalah tersebut, berkembang sistem penghantaran menggunakan etosom. Etosom merupakan nanovesikel elastis dengan kandungan fosfolipid dan alkohol (>20\%), yang dapat berpenetrasi menembus lapisan kulit terluar stratum corneum. Mekanisme kerjanya diduga karena kandungan alkohol dan fosfolipid yang terdapat dalam etosom. Tujuan dari review artikel ini diharapkan dapat memberikan informasi terkait etosom sebagai penghantar untuk obat herbal hidrofilik. Metode yang digunakan yaitu dengan mengumpulkan berbagai jurnal seputar etosom sebagai penghantar obat herbal. Hasil menunjukkan etosom sebagai penghantar obat herbal meningkatkan permeabilitas obat. Etosom dapat digunakan sebagai penghantar obat herbal.

Kata kunci : Etosom, Hidrofil, Herbal, Topikal

\section{Outline}

- Pendahuluan

- Metode

- Hasil

- Pembahasan

- Kesimpulan

\section{Pendahuluan}

Sediaan obat herbal banyak mengandung zat aktif yang bersifat hidrofil. Pada sediaan topikal, hal ini menjadi masalah utama dalam proses penghantaran dan penetrasi obat menembus kulit. Kulit tersusun atas lapisan yang bersifat hidrofob, dengan lapisan terluar startum corneum yaitu lapisan berupa keratin dan sel-sel mati yang sulit ditembus. Sebagai upaya untuk mengatasi masalah tersebut, etosom digunakan sebagai sistem penghantar obat. Etosom merupakan sebuah vesikel yang tersusun atas fosfolipid, air, dan etanol. Etanol diduga memiliki pengaruh utama dalam peningkatan permease terhadap kulit (Touitou et al, 2000).

Etosom (dari luar ke dalam) tersusun atas molekul lipid, bagian hidrofob, lipid bilayer fosfolipid, bagian hidrofil dan inti etanolik. 


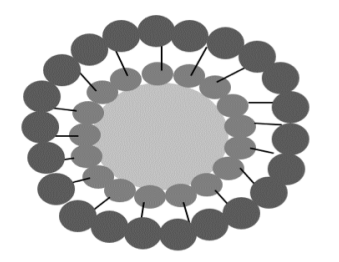

Gambar 1. Anatomi Etosom (Mishra et al, 2010)

Pada umumnya ukuran etosom berkisar pada 150-200 nm sehingga disebut sebagai nanovesikel elastis (Cevc et al, 2010).

Mekanisme etosom penetrasi ke dalam kulit yaitu etanol berpenetrasi ke dalam lipid intrasel dan meningkatkan fluiditas lipid membran sel dan menurunkan densitas lipid pada lapisan sel membran sehingga etosom yang mengandung zat aktif hidrofil dapat menembus lapisan lipid kulit terluar yang sulit ditembus yaitu stratum corneum (Dave, et al, 2010 ; Tyagi, et al, 2013 ; Akiladevi D, 2010 ; Upadhyay D, 2011).

Etanol mampu merusak struktur lapisan kulit terluar yaitu stratum corneum yang tersusun atas sel-sel hidrofob berupa keratin (Shaik, et al, 2013 ; Angadi, et al, 2013). Elastisitas etosom karena adanya kandungan etanol dan fosfolipid diduga sebagai faktor utama yang meningkatkan kemampuan obat untuk berpenetrasi lebih dalam (Cevc, 1996 ; Romero, 2013).

Tanaman dengan metabolit sekunder yang bersifat hidrofil, dapat digunakan etosom sebagai penghantar zat aktif pada sediaan obat topikal. Kandungan etanol didalam etosom sebagai enchancer dapat meningkatkan kemampuan obat untuk penetrasi (Touitou, 2000 ; B. Godin., 2003).

Tabel 1. Kelebihan dan Kekurangan Etosom

\begin{tabular}{|c|c|}
\hline Kelebihan Etosom & Kekurangan Etosom \\
\hline $\begin{array}{l}\text { Permeasi lebih tinggi (Prausnitz, } 2008 \text {; } \\
\text { Schoellhammer, 2014) dan kompatibilitas lebih } \\
\text { tinggi dibanding liposom konvensional (V. Dubey et } \\
\text { al, 2007) }\end{array}$ & $\begin{array}{l}\text { Fosfolipid kurang ekonomis (Verma and Pathak, } \\
\text { 2010). }\end{array}$ \\
\hline $\begin{array}{l}\text { Risiko toksik rendah, bahan yang terkandung sudah } \\
\text { disetujui untuk penggunaan farmasetika dan } \\
\text { kosmetika (Grace et al, 2014) }\end{array}$ & $\begin{array}{l}\text { Absorpsi tergantung ukuran molekul obat (Verma } \\
\text { and Pathak, 2010). }\end{array}$ \\
\hline $\begin{array}{l}\text { Dapat digunakan untuk molekul besar seperti } \\
\text { protein dan peptida (Verma and Fahr, } 2004 \text {; Sheer } \\
\text { and Chauhan, 2011) }\end{array}$ & $\begin{array}{l}\text { Sistem penghantaran obat terbatas untuk obat yang } \\
\text { poten (Verma and Pathak, 2010). }\end{array}$ \\
\hline $\begin{array}{l}\text { Meningkatkan permeasi, dapat digunakan dalam } \\
\text { bidang farmasetika, kosmetika dan kedokteran } \\
\text { hewan (Verma and Fahr, } 2004 \text {; Sheer and Chauhan, } \\
\text { 2011) }\end{array}$ & $\begin{array}{l}\text { Dapat timbul iritasi dan dermatitis saat penetrasi } \\
\text { (Verma and Pathak, 2010). }\end{array}$ \\
\hline \multicolumn{2}{|l|}{$\begin{array}{l}\text { Bersifat non-invasif, pasid dan non-toksik (Verma } \\
\text { and Fahr, } 2004 \text {; Sheer and Chauhan, 2011) }\end{array}$} \\
\hline $\begin{array}{l}\text { Selain pada molekul hidrofilik, dapat digunakan pada } \\
\text { molekul bersifat lipofilik atau amfifilik (Verma and } \\
\text { Fahr, } 2004 \text {; Sheer and Chauhan, 2011) }\end{array}$ & \\
\hline
\end{tabular}


Formula umum etosom merupakan fosfolipid, air dan etanol konsentrasi tinggi. Selain itu, dapat digunakan propilen glikol. Fosfolipid yang digunakan bervariasi tergantung bentuk sediaan yang akan dibuat, beberapa fosfolipid seperti (Distearoyl phosphatidylcholine, Egg phosphatidyl-choline, Soya-phosphatidylcholine, Dipalmitoyl phosphatidylcholine), selain itu juga dapat digunakan asam fosfatidik, fosfatidilserin dan lainnya dengan kandungan sekitar $0.5 \%-10 \% \mathrm{w} / \mathrm{w}$ (water/water).

Propilen glikol digunakan sebagai peningkat proses penetrasi atau pembasah, etanol membuat vesikel menjadi elastis dan merenggan gkan struktur lapisan kulit (Jain, 2001 ; Touitou, 1996, Touitou, 1998).

\section{Metode}

Sumber data yang digunakan dalam review adalah jurnal-jurnal internasional dan jurnal nasional. Pencarian jurnal dilakukan dengan website pencari jurnal, selain itu digunakan beberapa buku. Jurnal yang digunakan merupakan yang berhubungan dengan tema yaitu seputar etosom, sediaan transdermal, dan obat herbal yang bersifat hidrofilik

\section{Hasil}

Terdapat beberapa metode pembuatan etosom yaitu metode dingin, metode panas, metode disperse mekanik klasik, dan metode klasik (Barry, 2001 ; Biju, 2006)

Pada metode dingin, zat aktif, fosfolipid, etanol dan glikol dicampurkan dan diaduk kuat menggunakan mixer hingga seluruh material larut kedalam etanol, kemudian dipanaskan pada suhu $30^{\circ} \mathrm{C}$.

Pada saat yang sama, panaskan air dengan suhu yang sama, lalu campurkan air ke campuran etanol dan aduk dengan kuat. Pada proses penurunan ukuran vesikel, digunakan metode sonikasi atau ekstrusi. Hasil etosom disimpan dalam lemari pendingin (Grace, et al, 2014).

Pada metode panas, lipid didispersikan ke air pada suhu 400o $C$ hingga terbentuk fase koloid. Etanol dan glikol dicampurkan secara terpisah pada suhu yang sama. Ekstrak tanaman ditambahkan ke dalam solven yang kelarutannya sesuai. Fase organik ditambahkan ke fase air. Penurunan ukuran partikel dilakukan dengan metode sonikasi atau ekstrusi (Grace et al, 2014).

Pada metode dispersi mekanik klasik, fosfolipid dan ekstrak tanaman dilarutkan dalam kloroform : etanol dengan perbandingan 3:1. Pelarut organik dihilangkan dengan vaporator vakum dan divakum selama satu malam untuk menghilangkan sisa pelarut. Etosom didapatkan setelah dihidrasi (Grace et al, 2014).

Pada metode klasik, fosfolipid dan ekstrak tanaman dilarutkan dalam etanol dan dipanaskan hingga suhu $30 \circ \mathrm{C}$. selanjutnya ditambahkan air redestilasi dan diaduk pada kecepatan $700 \mathrm{rpm}$. Vesikel yang didapat dihomogenkan dengan cara dilewatkan pada membran polikarbonat (Grace et al, 2014). 


\section{Karakterisasi etosom}

Dalam karakterisasi etosom terdapat beberapa metode. Bentuk dan ukuran vesikel, bentuk vesikel dapat ditentukan secara visual menggunakan SEM (Scanning Electron Microscopy) dan TEM (Transmission Electron Microscopy) dan distribusi ukuran partikel dapat ditentukan menggunakan metode Dynamic Light Scattering dan spektroskopi korelasi foton. Potensi Zeta, menggunakan zeta meter untuk menentukan permukaan partikel yang digunakan untuk memprediksi stabilitas etosom (Grace, et al, 2014).

Efisiensi jerapan Obat, dapat diukur dengan teknik ultrasentrifugasi, kolom sentrifugasi kecil dan juga spektrofotometer floresensi. Evaluasi fisikokimia berupa organoleptik, homogenitas, pH dan viskositas etosom gel dan rheologinya diukur (Grace et al, 2014). Turbiditas, dapat diukur dengan nephalometer (Rakesh, 2012).

Interaksi vesikel dan kulit, dapat menggunakan confocal laser scanning microscopy, mikroskopi floresensi, TEM, dan Eosin Hematoxylin Staining untuk menentukan interaksi vesikel dan kulit, permeasi dan penetrasi obat menembus kulit. Interaksi fosfolipid dan etanol, dapat ditentukan dengan 319-nmr dan dengan metode Differential Scanning Colorimetric. Deformabilitas, diukur melalui metode ekstrusi (Grace et al, 2014).

Pelepasan obat, secara in vitro dapat dilakukan dengan difusi sel Franz dengan membran artifisial atau biologis atau dapat dengan metode dialysis bag diffusion. Kandungan obat, ditentukan dengan metode HPLC. Pengukuran aktivitas tegangan permukaan, diukur dengan Du nuoy Ring Tensiometer untuk larutan berbasis air (Grace et al, 2014). Stabilitas Etosom, dievaluasi berdasarkan efisiensi jerapan dan ukuran partikel, hal ini bergantung pada komposisi fosfolipid pada etosom (Sheo et al, 2010).

\section{Pembahasan}

Telah diketahui etosom merupakan salah satu sistem penghantar obat yang umumnya digunakan untuk sediaan topikal. Pada sediaan topikal, kulit merupakan sasaran utama sebagai media penetrasi obat. Kulit merupakan lapisan terluar tubuh yang melindungi tubuh dari substansi asing. Kulit tersusun atas lapisan sel-sel, yang bersifat hidrofob. Lapisan kulit terluar tersusun atas puluhan sel yang mengandung keratin dan merupakan lapisan sel yang paling sulit ditembus. Stratum corneum merupakan lapisan terluar. Sifatnya yang hidrofob membuat kulit tahan air. Stratum corneum dapat ditembus dengan zat yang memiliki sifat serupa dengan hidrofob.

Masalah utama yang muncul dengan kulit yaitu sulitnya menembus lapisan kulit. Terutama bagi zat aktif yang bersifat hidrofilik. Zat aktif yang bersifat hidrofilik banyak yang berasal dari tanaman herbal. Tanaman herbal dengan kandungan metabolit sekunder yang bersifat hidrofilik cenderung memiliki permeabilitas yang buruk pada sediaan topikal. Maka dari itu dibuat sistem penghantar obat topikal berupa vesikel.

Vesikel yang sering dan umum digunakan adalah liposom. Terdapat perbedaan komposisi antara liposom dan etosom. Pada etosom digunakan etanol dan air, sedangkan pada liposom etanol tidak digunakan. 
Tabel 2. Penelitian yang menggunakan etosom sebagai penghantar obat herbal

\begin{tabular}{|c|c|c|c|c|}
\hline Zat Aktif & Aktivitas Biologis & $\begin{array}{l}\text { Masalah obat } \\
\text { konvensional }\end{array}$ & $\begin{array}{c}\text { Hasil sediaan dengan } \\
\text { etosom }\end{array}$ & Referensi \\
\hline $\begin{array}{c}\text { Ammonium } \\
\text { Glycyrrhizinate } \\
\text { (Glycyrrhiza glabra) }\end{array}$ & Anti inflamasi & Permeabilitas buruk & $\begin{array}{c}\text { Meningkatnya } \\
\text { permeabilitas dan } \\
\text { aktivitas anti inflamasi }\end{array}$ & Paolino et al, 2005 \\
\hline $\begin{array}{c}\text { Leucocyanidin dan } \\
\text { cyaniding (Sesbania } \\
\text { grandiflora) }\end{array}$ & Anti mikroba & Permeabilitas buruk & $\begin{array}{c}\text { Meningkatkan } \\
\text { permeasi transdermal }\end{array}$ & Nirved, 2012 \\
\hline $\begin{array}{l}\text { Sophocarpine, } \\
\text { sophoridine, matrine, } \\
\text { oxymatrine (Sophora } \\
\text { alopecuroides) }\end{array}$ & $\begin{array}{l}\text { Antidotum, } \\
\text { antikanker, } \\
\text { antiinflamasi }\end{array}$ & $\begin{array}{l}\text { Penetrasi perkutan } \\
\text { buruk dan rasa pahit }\end{array}$ & $\begin{array}{l}\text { Meningkatkan } \\
\text { penghantaran obat dan } \\
\text { stabilitas obat }\end{array}$ & Zhou et al, 2010 \\
\hline $\begin{array}{l}\text { Matrine, oxymatrine } \\
\text { alkaloid (Sophora } \\
\text { flavescens) }\end{array}$ & $\begin{array}{l}\text { Kardioprotektor, } \\
\text { antiinflamasi }\end{array}$ & Bioavailibilitas rendah & $\begin{array}{l}\text { Memperbaiki permeasi } \\
\text { perkutan }\end{array}$ & Zhou et al, 2010 \\
\hline $\begin{array}{c}\text { Curcumin (Curcuma } \\
\text { longa) }\end{array}$ & Anti inflamasi & Durasi kerja & $\begin{array}{c}\text { Memperpanjang durasi } \\
\text { kerja obat }\end{array}$ & Zhao et al, 2013 \\
\hline $\begin{array}{l}\text { Lycopene (Solanum } \\
\text { lycopersicum) }\end{array}$ & $\begin{array}{l}\text { Antioksidan dan } \\
\text { antiinflamasi }\end{array}$ & Durasi kerja & $\begin{array}{c}\text { Meningkatkan aktivitas } \\
\text { obat }\end{array}$ & Ascenso et al, 2013 \\
\hline $\begin{array}{l}\text { Cathecin (Camellia } \\
\text { sinensis) }\end{array}$ & Antioksidan & $\begin{array}{l}\text { Kemampuan penetrasi } \\
\text { dan permeasi buruk }\end{array}$ & $\begin{array}{l}\text { Meningkatkan } \\
\text { permeabilitas }\end{array}$ & Ramadon et al, 2017 \\
\hline $\begin{array}{l}\text { Kafein, asam klorogenat } \\
\text { (Caffea Arabica L.) }\end{array}$ & Antiselulit & $\begin{array}{l}\text { Kemampuan penetrasi } \\
\text { dan permease rendah }\end{array}$ & $\begin{array}{c}\text { Meningkatkan } \\
\text { permeabilitas dan } \\
\text { kemampuan penetrasi }\end{array}$ & Zam Zam, 2019 \\
\hline $\begin{array}{l}\text { Hesperidin, naringenin } \\
\text { (Citrus hystrix D.C) }\end{array}$ & antioksidan & Permeabilitas rendah & $\begin{array}{c}\text { Meningkatkan } \\
\text { kemampuan penetrasi } \\
\text { dan permeabilitas }\end{array}$ & Muzuka, 2018 \\
\hline $\begin{array}{c}\text { Ekstrak Terminala } \\
\text { chebula }\end{array}$ & $\begin{array}{l}\text { Antioksidan, } \\
\text { antiinflamasi }\end{array}$ & $\begin{array}{l}\text { Permeabilitas rendah, } \\
\text { efektivitas oral rendah }\end{array}$ & $\begin{array}{l}\text { Meningkatkan aktivitas } \\
\text { obat dan permeabilitas }\end{array}$ & Grace et al, 2018 \\
\hline
\end{tabular}

Etanol dapat meningkatkan kemampuan penetrasi dan permeabilitas obat. Etanol mampu merusak struktur stratum corneum pada kulit dengan cara melunakkan dan merenggangkan sel-sel pada stratum corneum sehingga etosom yang mengandung zat aktif hidrofilik dapat menembus kulit. Selain itu, sifat etosom yang elastis memudahkan etosom untuk masuk diantara celah sel dalam lapisan kulit dan berpenetrasi. Etosom memiliki kemampuan penetrasi lebih tinggi dibandingkan dengan liposom. Liposom dapat menghantarkan obat hingga lapisan terluar kulit yaitu stratum corneum, sedangkan etosom mampu berpenetrasi menembus stratum corneum. Alasan etosom mampu berpenetrasi dan menghantarkan lebih dalam diduga karena efek kombinasi dari fosfolipid dan etanol konsentrasi tinggi dalam etosom (Akbarzadeh, 2013; Shilakari, 2013). 
Etanol dapat meningkatkan kemampuan penetrasi dan permeabilitas obat. Etanol mampu merusak struktur stratum corneum pada kulit dengan cara melunakkan dan merenggangkan sel-sel pada stratum corneum sehingga etosom yang mengandung zat aktif hidrofilik dapat menembus kulit. Selain itu, sifat etosom yang elastis memudahkan etosom untuk masuk diantara celah sel dalam lapisan kulit dan berpenetrasi. Etosom memiliki kemampuan penetrasi lebih tinggi dibandingkan dengan liposom. Liposom dapat menghantarkan obat hingga lapisan terluar kulit yaitu stratum corneum, sedangkan etosom mampu berpenetrasi menembus stratum corneum. Alasan etosom mampu berpenetrasi dan menghantarkan lebih dalam diduga karena efek kombinasi dari fosfolipid dan etanol konsentrasi tinggi dalam etosom (Akbarzadeh, 2013; Shilakari, 2013).

Selain itu, pada obat herbal terdapat beberapa batasan seperti sifat zatnya yang tidak stabil pada $\mathrm{pH}$ asam, masalah kelarutan dan absorpsi dapat menyebabkan kadar zat aktif menurun hingga di bawah konsentrasi terapeutik pada plasma yang menyebabkan penurunan kerja obat. Kebanyakan tumbuhan mengandung zat aktif yang bersifat hidrofil dan penyerapannya buruk karena ukuran molekulnya yang besar sehingga difusi pasif terhambat, dan kelarutan lemak yang buruk sehingga membatasi kemampuan obat untuk menembus membrane lipid (Pawar et al, 2015).

Pada hasil penelitian menunjukkan bahwa etosom mampu meningkatkan permeabilitas dan kemampuan penetrasi obat. Namun terdapat beberapa penelitian yang menunjukkan hasil yang tidak signifikan pada penggunaan etosom sebagai penghantar obat.

\section{Kesimpulan}

Etosom sebagai penghantar obat herbal hidrofilik dapat meningkatkan permeabilitas dan kemampuan penetrasi obat pada zat aktif tertentu. Sistem penghantaran obat masih dapat diteliti lebih lanjut dan dikembangkan.

\section{Daftar pustaka}

Akbarzadeh, Abolfazl, Rogaie Rezaei-Sadabady, Soodabeh Davaran, Sang Woo Joo, Nosratollah Zarghami, Younes Hanifehpour, Mohammad Samiei, Mohammad Kouhi And Kazem Nejati-Koshki. 2013. Liposome: Classification, Preparation, And Applications. Nanoscale Research Letters 8:102.

Akiladevi D, Sachinandan Basak. 2010. Ethosomes A Noninvasive Approach For Transdermal Drug Delivery. International Journal Of Current Pharmaceutical Research;ISSN- 0975-1491, Vol 2, Issue 4.

Angadi, J., Sai Sowjanya K , Nama Sreekanth, Karuna B, Chandu Babu Rao. 2013. Ethosomes: A Novel Drug Carrier For Transdermal Drug Delivery. International Journal Of Innovative Drug Discovery; Vol 3/lssue 1.

Ascenso A, Pinho S, Eleutério C, et al. 2013. Lycopene from tomatoes: vesicular nanocarrier formulations for dermal delivery. J Agric Food Chem. 61(30):7284-7293 
Barry B W. 2001. Is Transdermal drug delivery research still important today. Drug Discovery Today. 6(19): $967-971$.

Biju S S, Sushama T, Mishra P R, Khar R K. 2006. Vesicular systems: An overview. Ind. J. Pharma. Sci. 68(2): 141-153.

B. Godin and E. Touitou. 2003. Ethosomes: New prospects in transdermal delivery. Crit. Rev. Ther. Drug Carrier Syst. 20, 63.

Cevc G, Blume G, Schätzlein A, Gebauer D, Paul A. 1996. The skin: a pathway for systemic treatment with patches and lipid-based agent carriers. Adv Drug Deliv Rev. 18(3):349-378.

Cevc G, Vierl U. 2010. Nanotechnology and the transdermal route: A state of the art review and critical appraisal. J Control Release. 141(3): 277-299.

Dave, Vivek., Dhirendra Kumar, Shaila Lewis, Sarvesh Paliwal. 2010. Ethosome For Enhanced Transdermal Drug Delivery Of Aceclofenac. International Journal Of Drug Delivery 2; 8192.

E., Touitou. 1996. Composition of applying active substance to or through the skin. US Patent: 5716638.

E., Touitou. 1998. Composition of applying active substance to or through the skin. US Patent: 5540934.

E., Touitou, N. Dayan, L. Bergelson, B. Godin, and M. Eliaz. 2000. Ethosomes-novel vesicular carriers for enhanced delivery: characterization and skin penetration properties. Journal of ControlledRelease, vol. 65, no.3, pp.403-418.

Grace, Fatima., Rahul Raj S., Reshma I, Sandeep T, Shanmuganthan S and Chamundeeswari D. 2014. Herbal Ethosomes - A Novel Approach in Herbal Drug Technology. American Journal of Ethnomedicine Vol 1 No. $4: 226-230$.

Grace, Fatima, Suganya K., Shanmugantan S. 2018. Development Of Terminalia Chebula Loaded Ethosomal Gel For Transdermal Drug Delivery. Asian Journal of Pharmaceutical and Clinical Research Vol 11, Issue 12.

Jain N K, Advances in controlled and novel drug delivery. 2001. 1st edition. New Delhi. CBS Publication. 428-451.

Mishra, Dinesh \& Balekar, Neelam \& Dhote, Vinod \& Mishra, Pradyumna. 2017. Ethosomes: A Novel Carrier for Dermal or Transdermal Drug Delivery.

Muzuka, Muhammad O.D., Adeltrudis Danimayostu dan Siti Jazimah Iswarin. 2018. Uji Antioksidan Etosom Ekstrak Daun Jeruk Purut (Citrus hystrix D.C.) sebagai Anti Penuaan Kulit dengan Metode DPPH. Pharmaceutical Journal of Indonesia. 3. 39-44. 
Nirved V Uppadhyay, Lokesh Vyash, Ganesh Prasad Mishra And Hemant M Joshi. 2012. Formulation And Evaluation Of Ethosomes Of Sesbania Grandiflora Linn. Seeds. Novel Science International Journal Of Pharmaceutical Science. 1(6):-274-275.

Paolino D, Lucania G, Mardente D, Alhaique F, Fresta M. 2005. Ethosomes For Skin Delivery Of Ammonium Glycyrrhizinate: In Vitro Percutaneous Permeation Through Human Skin And In Vivo Anti-Inflammatory Activity On Human Volunteers. J Control Release. 106, 99-110.

Pawar, Priyanka, Rajan Kalamkar, Ashish Jain, Shoyab Amberkar. 2015. Ethosomea: A Novel Tool for Herbal Drug Delivery. IJPPR Human Journals Vol 3 Issue 4.

Prausnitz MR, Langer R. 2008. Transdermal drug delivery. Nat Biotechnol. 26(11):12611268.

Rakesh R, Anoop Kr. Ethosomes For Transdermal And Topical Drug Delivery. 2012. International Journal Of Pharmacy And Pharmaceutical Sciences; Vol 4, Suppl 3.

Romero EL, Morilla MJ. 2013. Highly deformable and highly fluid vesicles as potential drug delivery systems: theoretical and practical considerations. Int J Nanomedicine. 8:3171-3186.

Ramadon, Delly, Goldie Aisha W., and Efionora Anwar. 2017. Novel Transdermal Ethosomal Gel Containing Green Tea (Camellia sinensis L. Kuntze) Leaves Extract: Formulation and In vitro Penetration Study. J Young Pharm ; 9(3): 3336-340.

Schoellhammer CM, Blankschtein D, Langer R. 2014. Skin permeabilization for transdermal drug delivery: recent advances and future prospects. Expert Opin Drug Deliv. 11(3):393-407.

Shaik, S., Shaheda Sultana Shaik, V.Vasu Naik, Madhuri K. 2013. Ethosomes-An Emerging Approach For Vesicular Delivery System. International Journal Of Universal Pharmacy And Bio Sciences.

Shilakari, Gyati, Davinder Singh, Abhay Asthana. 2013. Novel Vesicular Carriers For Topical Drug Delivery And Their Application's. Int. J. Pharm. Sci. Rev. Res., 21(1); 14, 7786.

Sheer A, Chauhan M. 2011. Ethosomes as vesicular carrier for enhanced transdermal delivery of Ketoconazole - Formulation and Evaluation. IJPIs J. Pharm. Cosmetol. 1(3):114.

Sheo D.M, Sunil K.P, Anish K.G, Gyanendra K.S, Ram C.D. 2010. Formulation development and evaluation of ethosome of stavudine. Ind. J. Pharm. Edu. Res. 44(1): $102-108$. 
Tyagi, Lalit K., Saurabh Kumar, Shambhu Sharan Maurya and Mohan Lal Kori. 2013. Ethosomes: Novel Vesicular Carrier For Enhanced Transdermal Drug Delivery System. Bulletin Of Pharmaceutical Research. 3(1):6-13.

Upadhyay N, Mandal S, Bhatia L, Shailesh S, Chauhan P. 2011. A Review On Ethosomes: An Emerging Approach For Drug Delivery Through The Skin. Recent Research In Science And Technology. 3(7): 19-24.

Verma DD, Fahr A. 2004. Synergistic penetration enhancement effect of ethanol and phospholipids on the topical delivery of cyclosporin A. J. Control. Release. 97(1):55-66.

Verma P, Pathak K. 2010. Therapeutic and cosmeceutical potential of ethosomes: An overview. J. Adv. Pharm. Technol. Res. 1(3):274-82.

V.Dubey,D.Mishra,andN.K.Jain. 2007. Melatonin loaded ethanolic liposomes: physicochemical characterization and enhanced transdermal delivery, European Journal of Pharmaceutics and Biopharmaceutics,vol.67,no.2,pp.398-405.

Zam-zam, Andi N., Latifah Rahman, Sartini, Subehan Lallo, Aznah Marzuki. 2019. Preparasi Etosom Ekstrak Etanol Biji Kopi (Coffea Arabica L.) Menggunakan Variasi Konsentrasi Soya Lesitin dan Etanol. Majalah Farmasi dan Farmakologi. 23(1):1-4

Zhao YZ, Lu CT, Zhang Y, et al. 2013. Selection of high efficient transdermal lipid vesicle for curcumin skin delivery. Int J Pharm. 454(1): 302-309.

Zhou Y, Wei Y, Liu H, Zhang G, Wu X. Preparation And In Vitro Evaluation Of Ethosomal Total Alkaloids Of Sophora Alopecuroides Loaded By A Transmembrane Ph-Gradient Method. PMCID: PMC2974122 